\title{
CAN MEMORY TRAINING POSITIVELY AFFECT THE SKILLS OF LEARNING A FOREIGN LANGUAGE AND SUPPORT LEARNING ENGLISH BY OLDER STUDENTS?
}

\section{EXPERIMENT CONDUCTED AT THE UNIVERSITY OF THIRD AGE AT THE UNIVERSITY OF WROCŁAW}

\author{
Agata KozAK agata22kozak@gmail.com \\ University of Wrocław, Poland \\ JACEK GULANOWSKI jacek.gulanowski@gmail.com \\ University of Wrocław, Poland
}

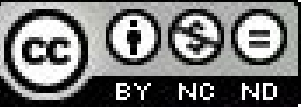

\section{ABSTRACT}

The experiment covered in this paper was conducted from November 2011 until February 2012 in the University of Third Age at the University of Wrocław in Poland as a part of the Third Age and New Technologies (TANT) project which was realised as a Grundtvig partnership programme. The aim of the experiment was to determine whether memory training can positively affect learning a foreign language (English) by senior students.

Key words: lifelong learning, adult education, third age, senior students, memory training, English learning

Nowadays, we incessantly observe and experience dynamic changes in the most important spheres and areas of human existence. Technological development, social and economic transformations, force us to search for ways to adjust to living in a "fluid" reality. One of the best ways is to carry out the idea of continuing education - a struggle to prevent knowledge from becoming outdated, its continuous broadening, professional updating, and building the knowledge based society. Lifelong learning is the basic requirement that is being demanded from members of the information society and not keeping up with the changing world may result in exclusion. "In 2002 the Resolution of the Council of the European Union determined lifelong learning as a phenomenon that should concern learning from kindergarten to the retirement age, including the entire learning spectrum: formal, out of regular, and informal. Learning should concern the whole, lifelong activity that is aimed at knowledge and skill development in personal, civic, social, and employment-oriented perspective" (Konieczna-Woźniak 2005, p. 60). When talking about lifelong learning, the emphasis is put only on adult education of people who are professionally active, paying little attention to the education of elderly people. However, lifelong learning is not only a necessity but is also becoming a certain way of life which concerns seniors as well. 


\section{THIRD AGE AND NEW TECHNOLOGIES PROJECT}

The experiment covered in this article was a part of the Third Age and New Technologies (TANT) project which was realised as a Grundtvig partnership programme. The coordinator of the project was the University of Third Age at the University of Wroctaw. The partners of the project were: Association E-SENIORS (France), Asociación de Alumnos "Ripense" de la Escuela Oficial de idiomas en Rivas (Spain) and Hatay Bakim Rehabilatosyon ve AILLE DANIŞMA MERKEZİ (Turkey).

The goal of the partnership was to organize experimental computer courses in ICT or in English (depends on the participating organization) for seniors in the 2011/2012 academic year. The program of the course would consist of learning basic computer skills or basic English. The goal was that elderly students, who do not know how to use computers or who do not speak English well enough to communicate, could be able to achieve quite good computer or language skills, so that they would be able to continue learning without a tutor and break psychological barriers, with the help of younger instructors. After the courses were completed, research on the senior education process was conducted. The information acquired during the research was posted on the web-site of the project. The project had an intergenerational dimension as well, because instructors and researchers were from the younger generation (Aims and rules).

\section{THE EXPERIMENT}

The experiment was conducted from November 2011 until February 2012 at the University of Third Age at the University of Wrocław in Poland as a part of the TANT project. The aim of the experiment was to determine whether memory training can positively affect learning a foreign language (English) by senior students.

The participants of the experiment were 24 students of the University of Third Age in the University of Wrocław divided into two groups: the experimental and the control group. The division was based on the initial level of English of the participants. The experimental group (beginner and intermediate) consisted of 10 students (the initial number of students was 13, however, 3 of them dropped out after the first classes), the control group (intermediate and upper intermediate) consisted of 14 students. The age of the participants ranged from 60 to 95 .

The independent variable of the experiment was the participation in memory training classes, whereas the dependent variable were the English skills of the students as measured by the tests. The aim of the experiment was to determine whether there is a correlation between taking part in the memory training classes and the achievements in learning English of the older students.

The decreasing quality and effectiveness of seniors' memory is considered to be one of the obstacles in senior learning and we presumed that this should be especially visible in case of learning a foreign language which largely consists of learning and memorising new words and terms.

\section{CONDUCTION OF THE EXPERIMENT}

Firstly, the idea was to divide the participants into two groups, equal in size and in the level of English. However, after the initiatory test it turned out that 
most of the students fell into the "intermediate" category regarding their English skills and there were a few who were beginners and a few who were upper intermediate. Before and after taking the initiatory tests (and before the results were known) many of the students made remarks regarding the division into the two groups and stated that they refuse to take part in the classes if they are to be in a group which would consist of significantly more or less advanced people. Therefore, it had been impossible to divide them into two "equal" groups (regarding the number of students, their English skills and the programme of the classes) as such a division would result in numerous drop-outs. The beginner and intermediate students have been assigned to one group and the intermediate and upper intermediate ones to the other. The first group became the experimental group, the second the control group.

The experimental group attended weekly English classes as well as regular memory training workshops, while the control group attended English classes only.

\section{MEMORY TRAINING AS A METHOD OF COMPETENCE TRAINING}

Trainings, in the sense of courses, are used mainly in enterprises for professional updating, and workers' professional development. In education, trainings occurred for the first time in the 1990s and nowadays they often concern the area of adult education. In the pedagogy dictionary issued by the Ossollineum, training " $(. .$.$) is located in the area of inservice courses. Activities repetition in order to$ form or consolidate skills (complex) as well as to increase the level of efficiency of the skills performance is essential for the training. Automatism in doing things, in other words - forming of a habit, should be the final result of the training" (Skibinska 2005, p. 211). But the term itself can be understood in narrower or wider sense. First one concerns reactive behavior - simple, uncomplicated activities which take short time to be taught. They can be also named habitual activities and they are indispensable in work which concerns doing simple things repeatedly. "The final result of the training, which is understood this way, will be the obtaining or the developing of certain skills (understood as intentionally made, intellectual and physical actions which can be trained and transformed into a habit)" (Skibińska 2005, p. 213). This kind of training can be named the training of skills, and represents the narrow sense of the term.

The term in wider sense concerns preparation "(...) to do or develop complex activities (on purpose) which will refer in a limited scope to reactive behavior. A result of the term training being understood in such a way will be competences (...)"(Skibińska 2005, p. 214). Jost Reischmann considers knowledge, understanding, skills, and self-confidence to be the elements of a competence. So the competence training is not just about exercising, but also about transferring the knowledge and arousing reflections among training participants. Except for providing participants with information and explanations, a trainer's duty is to ensure participants' safety, support them, and encourage, which results in building participants' feeling of self-confidence. The memory training, as a method that stimulates the learning process of elderly people which was carried out during the experiment was the competence training. 


\section{MEMORY TRAINING WORKSHOPS}

The classes of the memory training were being conducted between November, $23^{\text {rd }} 2011$ and February, 15 ${ }^{\text {th }}$ 2012. Ten seniors (students of the U3A) participated. The memory training consisted of both common and individual exercising of methods that stimulate memorizing and bringing back information from the memory, as well as developing imagination and creativity. All presented techniques were based on using imagination and associations - "a live picture" as Tony Buzan once said (Buzan 2005). The course lasted for 15 didactic hours (45 minutes). Classes were held twice a week every other week (each meeting lasted for 1,5h). During the classes, participants learnt memorizing methods like the chain method, the lap method, the Roman room method, the method of memorizing words and phrases in foreign language, and mind maps.

The first meeting introduced the specificity of the memory training and consisted of "opening" the students to use their imagination and to create amazing stories in participants' minds. This part was exercised by trying to finish the sentences like "What would happen if I was invisible for one day?", "What kind of benefits and problems would people have if they had three legs?", "If I was a king, what would my day be like?", "What would I do if I was a shipwrecked sailor on an desert island?".

Next, we started to train the first method - the chain method of associations. This technique is used to remember a short row of various pieces of information (e.g. a shopping list) in an appropriate order - joining by association one element of the row with another.

Another technique exercised was the lap method which consists in using keypictures to link them with the information that needs to be remembered. To build the system of picture bookmarks one needs to think up wordpictures which are similar to the figures from 1 to 10 . For example, a digit 2 has a similar shape to a swan, 4 looks similar to a boat, 7 has a similar shape to a scythe, 6 looks similar to the shell of a snail. The task is completed when one associates the list of words with the keypictures.

Then, we practiced the roman room technique which consists in "putting" the information we need in a space - a room. In this method, one should imagine oneself a room full of furniture (one's own room or just any imagined room). One should try to avoid "making a mess" and arrange indoors the information needed in specified order.

After that, we started to remember foreign words and expressions - mostly English. This method consists in creating "substitutes" for hard, unclear or inexplicable words. Substitutes are words or blends of words from our native language which sound similar to a word from a foreign language. It is very important to associate these two words.

The last method was the mind maps method - the memory notes. Traditional notes contain sentences and numbers, usually written in a line. Mind maps break monotony and engage associations and imagination in a memorizing process. In order to create one's own mind map, one should write a keyword in the middle 
of a white sheet of paper. This keyword depicts the main subject. One should draw lines from the main keyword, along which other keywords will be written or drawn. Terms, signs, symbols, pictures, and colors are important when creating a mind map. Such a multidimensional and colorful mind map allows to memorize easier and speeds up learning.

All the classes had the character of a workshop - each of the methods was thoroughly explained, presented, trained during classes, and repeated by participants on their own as a part of additional exercises at home. After the course completion, participants filled anonymous evaluation survey. Seniors positively judged the classes, the methods, and involvement of the trainer. Some of the reactions are quoted below:

- "This is the first time I participate in such training, I am delighted, these methods stimulate me to think better, to compare more often, and to analyze".

- "It is a pity our training finished so fast, we hope it will be continued".

- "All of the methods were engaging and interesting. Very effective in exercising memory".

Participants were satisfied with the workshop - theoretical and practical character of the course, individual approach during classes, and numerous references to private experiences. The only reservations concerned short duration of the course. The main demand was to continue the course on an extended level.

\section{ENGLISH CLASSES AND TESTING}

The programme of the weekly English classes covered the basic and intermediate English skills. The focus was placed mostly on reading, speaking and also on writing, listening. During the classes such topics have been covered as: everyday language (asking about and expressing one's opinion, discussion, useful everyday phrases), culture (poetry, art, reading), leisure, British and American cultures (English poetry, the $\mathrm{BBC}$ ), differences (in vocabulary, spelling and pronunciation) between British and American English, nature (animals, wildlife). After each class students were assigned a homework: preparing a short speech on a certain subject or doing language exercises on their own. Firstly, only English had been spoken during the classes. However, it turned out that the participants in the experimental group could not manage to work this way, and Polish was also spoken during the classes of the control group.

Participants both from the control and experimental group underwent regular testing of their English language skills. The initiatory test (which was also the method of determining their initial English language skills and the basis for the division of the participants into the groups) consisted of questions regarding general knowledge of English. The participants had to answer various questions (in English) regarding different aspects of everyday life. During the next tests, participants from both groups had to name Polish equivalents of words they had learned during previous classes. The final test consisted of two parts. First one was naming of Polish equivalents of words learned during the whole course. The 
second part was answering of various questions (in English) regarding everyday life. The initiatory and final tests were identical for both groups. The tests taken during the course of English classes had been different for both groups as the programme would slightly vary. However, in the final test only the terms which had come up during classes for both groups had been mentioned. As there had been quite a problem with cheating during previous tests, the final test was filled out anonymously by the participants (only the number of the group has not been anonymous). The previous tests were not anonymous as it was also our attempt to track the progress of individual students.

There have been some difficulties in conducting the experiment - both regarding the English classes as well as testing both groups of students. The most important ones were cheating (students were willing to turn out best in the tests, therefore they either consulted answers with each other or tried to peep into their notebooks) and absences ( mostly due to health and family issues). The classes did not always take place on a weekly basis as there have been some breaks due to holidays and the over-all organisation of the academic year at the University of Third Age.

\section{OUTCOME}

The average test results of both groups were compared and the difference between them (the percentage of correct answers) in order determine the possible correlation between the two variables (as indicated in Table 1).

Tab. 1. Results of the tests and the difference between the control and the experimental group

\begin{tabular}{|l|c|c|c|}
\hline & Control group & Experimental group & Difference \\
\hline Initial test & $79.1 \%$ & $69.1 \%$ & $10 \%$ \\
\hline Second test & $72.5 \%$ & $55 \%$ & $17.5 \%$ \\
\hline Third test & $67.5 \%$ & $58.6 \%$ & $8.9 \%$ \\
\hline Final test & $83.2 \%$ & $71.2 \%$ & $12 \%$ \\
\hline
\end{tabular}

Source: Author

A fall and rise of average test results of both groups is clearly visible (as demonstrated by Fig. 1). In the case of the control group the second test turned out better than the third, results of the third test were the lowest and the results of the final test were even above those of the first one. In the case of the experimental group the second test turned out the worst, there was a slight improvement in the results of the third test and the final test turned out slightly better than the first one.

Furthermore, to measure the progress of both groups in learning English, the results of the initial test have been subtracted from the results of the final test. The difference for the control group was $4.1 \%$ and for the experimental group: $2.1 \%$. Therefore, the control group turned out almost twice as well as the experimental group in terms of progress made during the course. However, the results are slightly distinct when comparing the difference between the best and the worst test results of the groups. For both groups the results of the final test were the best. 
The worst results were attained in the second (the experimental group) and the third (the control group) tests. In this case the difference for the control group was $15.7 \%$ and for the experimental group $16.2 \%$. Therefore, the experimental group achieved a greater progress when comparing the worst and the best test results.

Fig. 1. Average test results of the experimental and the control group

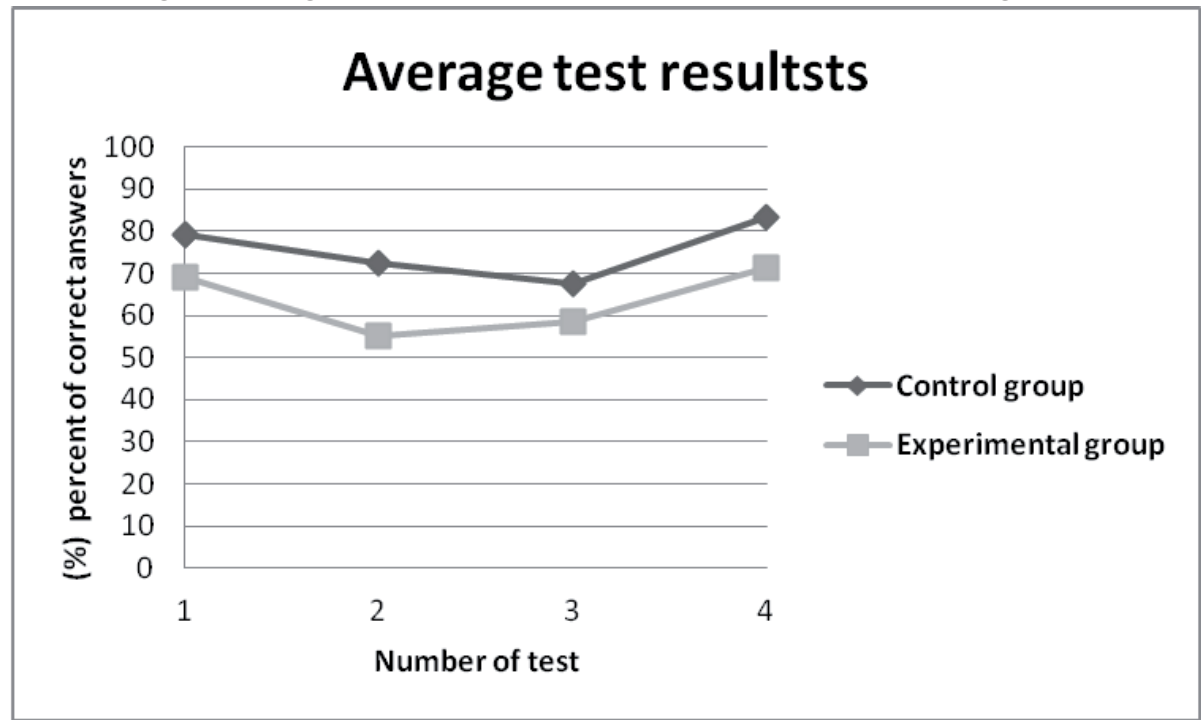

Source: Author

Fig. 2. Difference in test results between the control and the experimental group

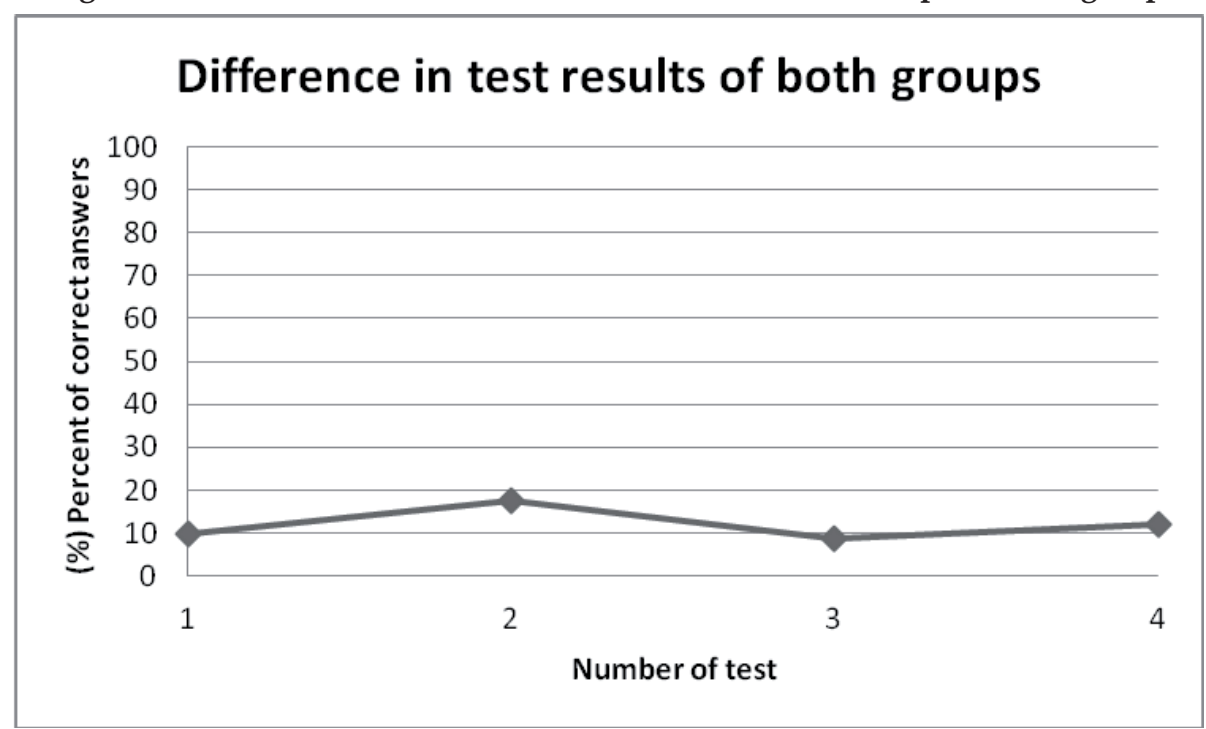

Source: Author 
The differences between the results of both groups were also compared (Fig. 2). They have been quite low (average: $12 \%$ ). However, comparison of the differences in the results of the initial and the final test demonstrates that the final difference was slightly higher than the initial (by $2 \%$ ). This can be understood as a proof that the control group made a greater progress in learning English than the experimental group, however, the difference is not significant.

In conclusion, the comparison of average test results of the experimental and the control group is ambivalent. When comparing all test results and the difference between the final and the initial test results of each group, the control group achieved better results. Also the difference in average test results indicates that the control group has made a slightly greater progress. However, when comparing the difference between the best and the worst results of each group, the experimental group has made a slightly greater progress. Therefore, it can be stated that there is almost no positive correlation between the two variables: the memory training classes and the English skills of older students.

\section{DISCUSSION OF THE RESULTS}

The experiment was not conducted in a laboratory but in a real University of Third Age, so in the same environment as the actual educational innovation would be put into use. This can be seen as both an advantage and a disadvantage of the experiment.

The disadvantages have already been mentioned. The absences of the participants, the irregularity of their participation in the classes have been quite a problem, especially in the case of the experimental group and it could have affected the over-all results of the experiment. However, it was a difficulty practically impossible to avoid. Had the participants been obliged to take part in every English class on a weekly basis, they would drop out of the classes completely. The participants were allowed one absence, but, as it turned, out personal issues (mostly family and health problems) have forced some of them to miss more classes.

The advantage of conducting the experiment in the conditions natural for foreign language learning by seniors is especially the fact that the experiment made it possible to find out how the whole idea of linking memory training and learning English would work in a real educational environment of older students.

Another disadvantage is the difference in the level of English skills of both groups. The differences between the beginners and the advanced who have volunteered for the experiment was so great, that it had been impossible to put participants of both of those categories into one group. In such a case, the advanced would be bored throughout the class or the beginners would find them too hard. As it has been mentioned before, many of the serious claimed they would not participate in the classes if the groups were mixed. The result would be the dropping out of most of the participants before the end of the experiment. Therefore, the division into the control and the experimental group was based on the level of English skills of the participants. 
There was an inner conflict in assuming both the position of the teacher and of the researcher. The teacher strives to help his students learn as much as they can and the researcher strives to carry out the experiment and gather data necessary for the discussion of results. So the whole experiment was largely a compromise between the researcher and the teacher (being the same person) as well as between him and the participants (students). And so for example the groups were divided regarding the statements of the participants, the "only English during class" policy was dropped in the experimental group, etc. On the other hand - the participants were regularly tested despite the participants' complaints who referred to it as stressful and unnecessary (even though they were informed in advance and the information was repeated numerously during the experiment that they will not get any grades for the tests, their personal results would not be made public and that the whole idea behind the classes is that an experiment is being conducted, so without tests there would not be any classes at all). However, the final test was taken anonymously in order to minimise the effects of possible cheating on the score.

Paradoxically, the experimental group turned out best in the tests which went beyond memorisation of words (the initial and the final tests), even though the memory training is supposed to positively affect mostly the skills of memorising. However, it must be also noted that the aim of the experiment was to determine whether there exists a positive connection between taking part in memory training and learning a foreign language, not the effects of using the memory training during English classes. So the effect of the memory training could be twofold. Firstly, it could improve the general quality of participants' memory and therefore positively affect their language learning. Secondly, the seniors could use the mnemonic techniques they learned during the training on their own (for instance: during home study for the next class).

Another paradox is that both of the groups turned out best in the first and the final test, even though the initial test was the easiest, but the final test the hardest as it covered the subjects of all classes, whereas the second and the third tests covered the subject of just the previous class. It must be remembered, however, that both of the groups would turn out quite poorly in the final test (perhaps with a few exceptions of the most advanced participants in the control group), had they not participated in the English classes. This is especially true in the case of the experimental group. Therefore, it can be stated that there was a significant progress in learning English in both of the groups.

It may be assumed that of all the over-all language skills, a talent for learning a foreign language is apparently more important than memorisation skills. The control group consisted of people who already knew at least one foreign language (including English) and were linguistically quite talented. The experimental group consisted mostly of people who did not know other foreign languages. Some of them have had no significant experience in learning any language (besides the compulsory school study of Russian which was of low quality in Poland) or have unsuccessfully tried to learn English in the past. There were two cases of participants from the experimental group who were advanced or fluent in a foreign language other than English and one of them was the highest scoring (100\% of 
correct answers in the third and in the final test) person in the experimental group, the other student displayed a consequent rise in the results of the tests $(41.6 \%$ in the initiatory test, $60 \%$ in the final test).

It must be noted that there were many positive reactions to memory training, positive impression of the participants of the experimental group expressed directly to the English language teacher during the classes and afterwards. As some of them have stated during conversations with the teacher: the training has made them more confident during the English classes. The question which cannot be answered when analysing the results of this experiment is whether the experimental group would have made such a progress if they had not participated in the memory training. However, in order to determine whether there is a positive correlation between memory training and learning a foreign language by senior students, an experiment should be conducted in a laboratory environment.

There was also a positive educational impact of the experiment: most of the participants (from both groups) decided to continue learning English after the end of the experiment and continue to regularly take part in English language classes at the University of Third Age. This should be seen as a positive result especially in the case of the beginners from the control group. So even though the experiment failed to determine the existence of a correlation between the two variables, it turned out to be successful in helping seniors to learn a foreign language and to keep learning after the end of the experiment, which was one of the goals of the TANT project.

English is becoming (or has already become) the lingua franca of the contemporary world, the "fluid" reality filled with technological innovations. Most of the elderly people (especially senior students) can clearly see this fact. However, they often see obstacles that supposedly stand in their way, of which their age and their decreasing learning skills are the most important. And yet the English classes organised for the seniors as a part of the TANT programme demonstrate that it is possible to learn during the third age and that the idea of Lifelong Learning can be successfully put into practice.

\section{BIBLIOGRAPHY:}

Buzan T. (2005), Use Your Memory, Pearson Education, Upper Saddle River.

Fabiś A. (ed.) (2005), Seniorzy w rodzinie, instytucji $i$ społeczeństwie: wybrane zagadnienia wspótczesnej gerontologii, Wydawnictwo Wyższej Szkoły Zarządzania i Marketingu, Sosnowiec.

Konieczna-Woźniak R. (2005), Seniorzy w społeczeństwie wiedzy i informacji [in:] Fabiś A. (ed.), Seniorzy $w$ rodzinie, instytucji i spoteczeństwie: wybrane zagadnienia wspótczesnej gerontologii, Wydawnictwo Wyższej Szkoły Zarządzania i Marketingu, Sosnowiec.

Podgórny M. (ed.) (2003), Człowiek na edukacyjnej fali: wspótczesne konteksty edukacji dorostych, Impuls, Kraków.

Skibińska E. (2005), Trening jako forma ksztatcenia dorostych. Nierozpoznany przez andragogike obszar [in:] Podgórny M. (ed.), Człowiek na edukacyjnej fali: wspótczesne konteksty edukacji dorostych, Impuls, Kraków.

\section{NETOGRAPHY:}

